Prepared in cooperation with the U.S. Environmental Protection Agency

\title{
Analysis of Streamflow-Gaging Network for Monitoring Stormwater in Small Streams in the Puget Sound Basin, Washington
}

Scientific Investigations Report 2012-5020 



\section{Analysis of Streamflow-Gaging Network for Monitoring Stormwater in Small Streams in the Puget Sound Basin, Washington}

By Christopher P. Konrad and Frank D. Voss

Prepared in cooperation with the U.S. Environmental Protection Agency

Scientific Investigations Report 2012-5020 


\title{
U.S. Department of the Interior \\ KEN SALAZAR, Secretary \\ U.S. Geological Survey \\ Marcia K. McNutt, Director
}

\author{
U.S. Geological Survey, Reston, Virginia: 2012
}

For more information on the USGS - the Federal source for science about the Earth, its natural and living resources, natural hazards, and the environment, visit http://www.usgs.gov or call 1-888-ASK-USGS.

For an overview of USGS information products, including maps, imagery, and publications, visit http://www.usgs.gov/pubprod

To order this and other USGS information products, visit http://store.usgs.gov

Any use of trade, product, or firm names is for descriptive purposes only and does not imply endorsement by the U.S. Government.

Although this report is in the public domain, permission must be secured from the individual copyright owners to reproduce any copyrighted materials contained within this report.

Suggested citation:

Konrad, C.P., and Voss, F.D., 2012, Analysis of streamflow-gaging network for monitoring stormwater in small streams in the Puget Sound Basin, Washington: U.S. Geological Survey Scientific Investigations Report 2012-5020, 16 p. 


\section{Contents}

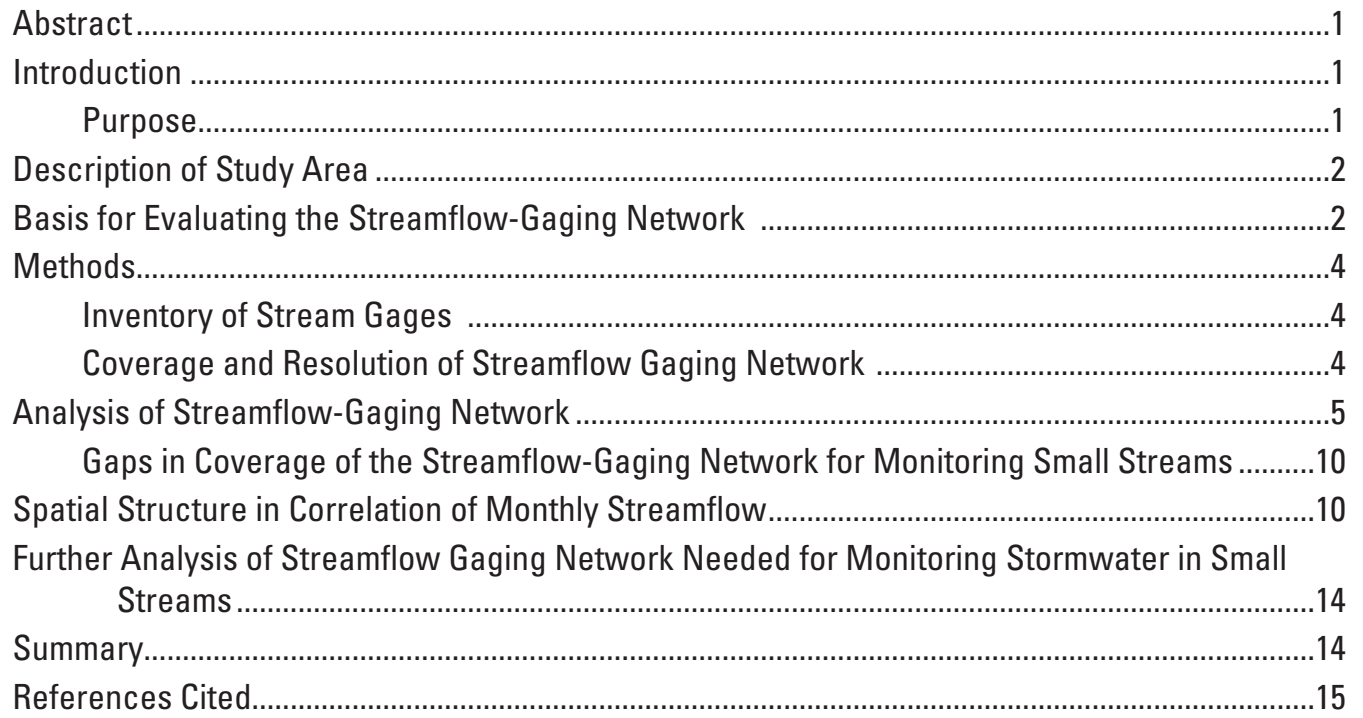

\section{Figures}

Figure 1. Map showing Puget Sound basin and the Puget Lowland ecoregion, Washington

Figure 2. Map showing streamflow gages and areas draining to active gages in the

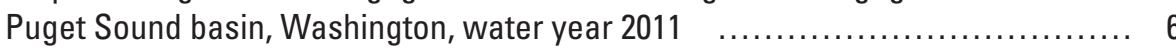

Figure 3. Graph showing distribution of active streamflow gages in the Puget Sound

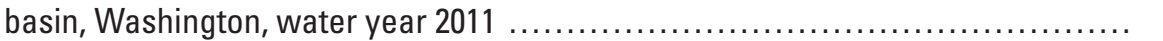

Figure 4. Graph showing distribution of active streamflow gages in the Puget Lowland,

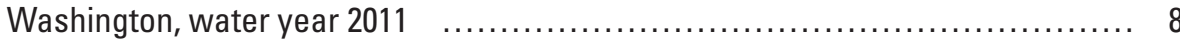

Figure 5. Graph showing distribution of active streamflow gages in urban areas of the

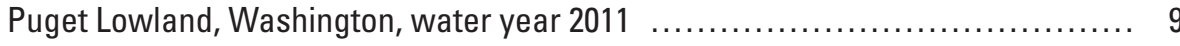

Figure 6. Map showing ungaged streams (not actively gages) and urban areas in the Puget Lowland, Washington, water year 2011

Figure 7. Graphs showing cumulative distribution of correlation coefficients for non-nested gage pairs and correlation coefficients of pairs of nested lowland gages, Puget Sound basin, Washington, water year 2011

Figure 8. Graph showing cumulative distribution of maximum correlation coefficient for lowland gages not including nested pairs, Puget Sound basin, Washington, water year 2011 


\section{Tables}

Table 1. Streamflow gages in the Puget Sound basin, Washington, operated between water years 1897 and 2011

Table 2. Number of streamflow gages in the Puget Sound basin, Washington, water year 2011

Table 3. Area draining to a streamflow gage in the Puget Sound basin, Washington, water year 2011

\section{Conversion Factors and Datums}

Conversion Factors

SI to Inch/Pound

\begin{tabular}{lcl}
\hline \multicolumn{1}{c}{ Multiply } & By & \multicolumn{1}{c}{ To obtain } \\
\hline Length & \\
\hline meter $(\mathrm{m})$ & 3.281 & foot $(\mathrm{ft})$ \\
kilometer $(\mathrm{km})$ & 0.6214 & mile $(\mathrm{mi})$ \\
\hline \multicolumn{3}{c}{ Area } \\
\hline square kilometer $\left(\mathrm{km}^{2}\right)$ & 0.3861 & square mile $\left(\mathrm{mi}^{2}\right)$ \\
\hline & Flow rate & \\
\hline cubic meter per second $\left(\mathrm{m}^{3} / \mathrm{s}\right)$ & 35.31 & cubic foot per second $\left(\mathrm{ft}^{3} / \mathrm{s}\right)$ \\
\hline
\end{tabular}

Datums

Vertical coordinate information is referenced to the North American Vertical Datum of 1988 (NAVD 88).

Horizontal coordinate information is referenced to the North American Datum of 1983 (NAD 83). Elevation, as used in this report, refers to distance above the vertical datum. 


\title{
Analysis of Streamflow-Gaging Network for Monitoring Stormwater in Small Streams in the Puget Sound Basin, Washington
}

\author{
By Christopher P. Konrad and Frank D. Voss
}

\section{Abstract}

The streamflow-gaging network in the Puget Sound basin was analyzed for its capacity to monitor stormwater in small streams. The analysis consisted of an inventory of active and inactive gages and an evaluation of the coverage and resolution of the gaging network with an emphasis on lowland areas. The active gaging network covers much of the Puget Lowland largely by gages located at sites on larger streams and rivers. Assessments of stormwater impacts and management will likely require streamflow information with higher spatial resolution than provided by the current gaging network. Monitoring that emphasizes small streams in combination with approaches for estimating streamflow at ungaged sites provides an alternative to expanding the current gaging network that can improve the spatial resolution of streamflow information in the region. The highest priority gaps in the gaging network are low elevation basins close to the Puget Sound shoreline and sites that share less than 10 percent of the drainage area of an active gage. Although small, lowland sites with long records of streamflow are particularly valuable to maintain in the region, other criteria for prioritizing sites in the gaging network should be based on the specific questions that stormwater managers need to answer.

\section{Introduction}

Stormwater is generated by rainfall and snowmelt that flows rapidly over the land surface and at shallow depths through soils. Land-surface changes associated with urban development including increased impervious area, reduced soil depths, and expansion of the drainage network increase the volume and rate of stormwater runoff from the land surface. Stormwater is a significant water-quality issue for the Puget Sound region because of its roles in transporting contaminants, nutrients, and sediment from the land surface to streams, wetlands, and estuaries, but also altering streamflow patterns that impact stream ecosystems. The Puget Sound Stormwater Work Group, a consortium of city, county, State, Tribal, and Federal agencies in western Washington, is coordinating regional stormwater monitoring and assessment as part of Phase II National Pollutant Discharge Elimination System (NPDES) permitting of municipal stormwater discharges. The Puget Sound Stormwater Work Group (2010) developed a monitoring strategy that includes assessing the status and trends in water quality and water quantity for small streams . Although the Work Group recommended randomized sampling of sites for the water-quality assessment, they recognized that the water-quantity assessment should incorporate existing streamflow gages to the extent possible for cost efficiency and availability of existing data. At the request of the U.S. Environmental Protection Agency (USEPA), the U.S. Geological Survey (USGS) investigated the network of streamflow gages operated by city, county, State, Tribal, and Federal agencies in the Puget Sound basin.

\section{Purpose}

Continuous daily records of streamflow provides information required for stormwater management including

1. Direct monitoring of status and trends in small streams receiving stormwater;

2. Inference of conditions in ungaged streams;

3. Development of standards or performance targets with an understanding of baseline (unaltered) streamflow; and

4. Evaluation of the effectiveness of management actions intended to reduce stormwater impacts. 
The goal of this investigation was to develop an inventory of active and inactive streamflow gages operated in the Puget Sound basin that collected continuous daily measurements of streamflow and to analyze the capacity of the streamflowgaging network to monitor status and trends of small streams draining lowland areas. This investigation describes the spatial and temporal coverage of the streamflow-gaging network with an emphasis on active gages in lowland areas. The results will inform further development of the regional streamflowgaging network for monitoring small streams with respect to municipal stormwater impacts.

\section{Description of Study Area}

Puget Sound is an estuary of the Pacific Ocean located in western Washington east of the Strait of Juan de Fuca and south of the Strait of Georgia (fig. 1). The Cascade Range and Olympic Mountains border the eastern and western sides of the lowland, respectively. The southern boundary of the basin is defined by the divide between the Chehalis River (outside of Puget Sound basin) and the Nisqually and Deschutes Rivers (inside of Puget Sound basin). The boundaries of Puget Sound basin generally used in regional planning extends west along the northern coast of the Olympic Peninsula to Cape Flattery and includes the San Juan Islands, the Skagit River and Nooksack River basins, and all coastal areas north of Deception Pass that are within the United States. Within these boundaries, the Puget Sound basin covers $36,670 \mathrm{~km}^{2}$.

The basin can be divided broadly around $200 \mathrm{~m}$ above sea level into lowland and mountain ecoregions (U.S. Environmental Protection Agency, 2011). The Puget Lowland was glaciated by Cordilleran ice sheet during the Frasier glaciation about 18,000 to 10,000 years before present. The ice sheet left large troughs, generally with a north-south orientation, and glacial drift (unconsolidated sediments) deposits forming the land surface. The lowlands have many plateaus and hills formed of glacial drift with wide river valleys. Small streams have incised valleys with steep hillslopes. In contrast, the Cascade Range and Olympic Mountains generally have steep hillslopes with exposed bedrock and narrow valleys. As a result, most of human development in the region has been concentrated in lowland areas.

\section{Basis for Evaluating the Streamflow-Gaging Network}

The streamflow-gaging network in the Puget Sound basin has developed over a century to serve various purposes. The earliest recorded gage, located on the Cedar River near Landsburg (USGS station 12117500), began operation in
August 1895 and is still active. Expansion of the network over time has been for a particular purpose only_ gages are located and operated at sites to provide information about water supply, hydropower production, and flooding on specific rivers and streams. As a result, the capacity of the network for monitoring stormwater in small streams depends in some part on gages that were not necessarily intended for this purpose.

Continuous daily streamflow records has many potential applications that support stormwater management under NPDES. This analysis focuses on information needs for monitoring status and trends in small streams. The value of a gage for monitoring small streams in the Puget Lowland depends on its location, period of record, and the quality of information collected at the site. Although some gages are valuable because of the length and quality of their record, other gages have attributes that are particularly suited for monitoring stormwater impacts. Gages in lowland areas with records from the mid- to late 20th century are particularly useful because of the recent concentration of human development (Konrad and Booth, 2002). In addition, the value of a gage depends on its contribution to the broader networkgages that fill gaps in time or space are particularly valuable. The Puget Sound Stormwater Work Group (2010) proposed to assess status and trends for urban streams with dense human populations and extensively modified land cover separately from rural streams, which may have less obvious hydrologic changes but nonetheless are impacted by stormwater. Based on these considerations, the analysis of the streamflow-gaging network focused on small lowland streams in urban and rural settings analyzing their spatial distribution and periods of record.

In addition to monitoring the status and trends of small streams, the streamflow-gaging network provides information to infer the status of ungaged sites and to link changes in stormwater production to land-cover changes and stormwater-management practices. In both of these cases, the need for streamflow information will be determined by the methods used for analysis. In general, inference of status at ungaged sites will require a gaging network with extensive spatial coverage but also high resolution to isolate particular basin characteristics (for example, surficial geology, soils, wetlands, land cover, and precipitation patterns) that may account for variable hydrologic responses among different streams. The capacity of a streamflow-gaging network for evaluating the effects of management practices depends on gaging small areas where specific practices or land uses can be resolved within a broader area that will have mixed practices and various historical land-cover changes. The current streamflow-gaging network is not likely to be sufficient for evaluation purposes, which will require focused data collection following a design specifically for evaluation (for example, Puget Sound Stormwater Work Group, 2010), but the current streamflow gaging network may contribute information to such an evaluation. 


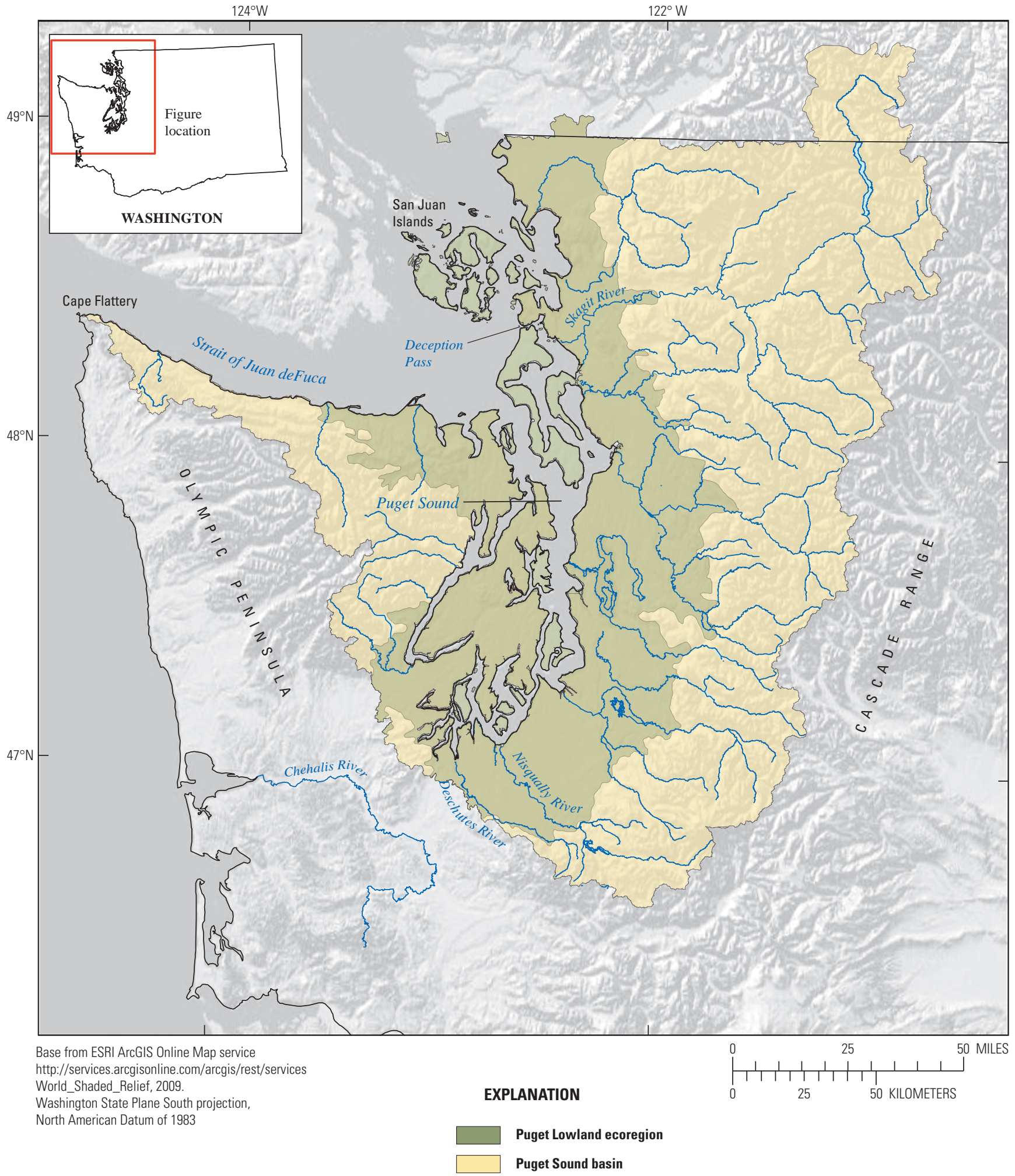

Figure 1. Puget Sound basin and the Puget Lowland ecoregion, Washington. 
Gages with long-term records are particularly useful in stormwater applications. Streamflow records spanning multiple decades that can be used to distinguish trends from variability. Continuous long-term records of streamflow at a site can be used as an index station to extend streamflow records at discontinued sites. Comparison of streamflow between two sites that have overlapping periods of record can be an effective method for detecting hydrologic change at one of the sites while accounting for regional climatic variability. Even records from sites that have been discontinued can be useful, for example, when combined with more recent monitoring information.

There is not definitive length of record for all stormwater applications. Trends related to urban development in Puget Lowland streams can be detected with about 10 years of record for some annual streamflow statistics (for example, annual maximum streamflow) but typically require 20 or more years for a greater level of certainty (Konrad and Booth, 2002). For comparisons between sites, about 10 years of record would be needed for an accurate estimate of statistics representing common flow characteristics, such as mean streamflow or median annual maximum streamflow, but not infrequent events.

Ten years is used in this analysis as the criterion for gages that are likely to be useful for various applications including assessing current status and future trends, extending streamflow records at sites with shorter records, and separating climatic variability from land-use effects on streamflow for the region. Gages with shorter records also may be useful depending on their particular period of record and physiographic attributes.

\section{Methods}

\section{Inventory of Stream Gages}

Public agencies, Native American Tribes, and private organizations in western Washington were contacted to identify the location of all current and historical gages collecting daily streamflow information and operated for 1 year or more. Period of record information was obtained from each agency operating the gage, but were not readily available for all gages with all missing periods clearly identified. Gage locations were entered into a geographic information system (GIS). Each gage was associated with the closest stream reach in the high resolution $(1: 24,000)$ National Hydrography Dataset (NHD) (U.S. Geological Survey, 2011).

Gages located farther than $100 \mathrm{~m}$ from the nearest stream were inspected to verify their location. Most of these gages were at headwater sites located upstream of the mapped extent of the stream network. Gages monitoring wetlands or engineered stormwater ponds that do not flow directly to a mapped stream were removed from the inventory. In other cases, gage coordinates were erroneous, corrected, and re-located. Some large river gages were located more than $100 \mathrm{~m}$ from the nearest mapped reach but had the correct coordinates. These discrepancies may be a result of (1) the distance between the centerline of the river represented by the hydrography and the riverbank where a gage would be located, (2) channel migration, or (3) errors in location of the gage or river. No attempt was made to manually locate gages or revise the NHD. Gages assigned to the same reach were examined to determine if they were at the same site (no intervening tributaries). Each unique site was entered into a database that includes the agencies operating gages at the site, the agency code for the gage, the starting water year of data collection, the ending water year of data collection (through 2011), and the estimated number of full years of record (table 1). Gages operating during water year 2011 were designated as active. Gages that included lowland area in their drainage basin were classified as "lowland" gages. Gages where the entire basin was outside of the lowlands were classified as "mountain" gages.

Table 1. Streamflow gages in the Puget Sound basin, Washington, operated between water years 1897 and 2011 (available for download at http://pubs.usgs.gov/sir/2012/5020/.

\section{Coverage and Resolution of Streamflow Gaging Network}

The coverage and resolution of the streamflow-gaging network in the Puget Sound basin was analyzed using simple overlays of gaged area with lowland and urban areas in a GIS. The drainage area for each gage was delineated by applying the ArcHydro flow accumulation algorithm to the $30 \mathrm{~m}$ resolution National Elevation Dataset (NED) in ArcGIS. The Puget Lowland boundary is the U.S. Environmental Protection Agency (2011) level 3 ecoregion. Urban areas were delineated using boundaries for incorporated cities and unincorporated urban growth areas were obtained from the Washington State Department of Ecology (2011a).

Basin boundaries for gages were compared to the Puget Sound watershed characterization analysis units (Washington State Department of Ecology, 2011b) and USGS gage basins delineated from high resolution digital elevation models (DEMs) (Falcone, 2011) to identify gross errors, which were corrected. The comparisons to other basin boundaries indicated widespread small errors in the delineation of basins for this study. The errors are a result principally of the spatial resolution of the $30 \mathrm{~m} \mathrm{NED}$, which does not accurately represent all surface divides and drainages, and the presence of engineered drainage systems that do not follow surface-flow paths. The boundary errors have little effect on 
the cumulative area gaged, but they do produce significant errors in the estimates of drainage areas of small gages and, as consequence, the analysis of the spatial resolution of the gaging network.

Network coverage was assessed in terms of the area draining to active and inactive gages. Coverage was calculated for the entire Puget Sound basin, the Puget Lowland, and urban areas in the Puget Lowland. Network resolution was assessed in terms of the incremental area for each active gage that does not include the area of upstream active gages. Cumulative distributions of incremental gaged areas were calculated for the Puget Sound basin, the Puget Lowland, and urban areas in the Puget Lowland.

The spatial resolution of the gaging network also was assessed by analyzing the correlation of monthly mean streamflow for pairs of gages in the Puget lowland. Kendall's tau rank correlation coefficient $(\tau)$ was calculated for time series of monthly mean streamflow (for example, mean streamflow for October 2001, November 2001, ..., September 2002) at each pair of gages that shared a common period of 1 year. There were 276 lowland gages and 21,868 pairs of gages with at least one year of overlapping records. The results of the correlation analysis were used to evaluate the capability of the current (water year 2011) streamflow-gaging network to support an index-station approach for estimating streamflow at ungaged sites. In addition, the correlation analysis provides information about the information gained and redundancy of nested gages that share drainage area.

\section{Analysis of Streamflow-Gaging Network}

The inventory of streamflow gages identified 776 sites where daily streamflow has been measured in the Puget Sound basin and 285 active gages where daily streamflow was measured in water year 2011 (fig. 2, table 1). Most active gages (232 sites) include some lowland area (table 2), although lowland area may be a small fraction of the total drainage area of these gages. Gages that include lowland, urban area constitute about 56 percent ( 157 gages) of all active gages in the basin.
Most of the Puget Sound basin (74 percent) is currently (2011) gaged, although less of the Puget Lowland (45 percent) and lowland urban areas (40 percent) are gaged (table 3). The cumulative distributions of sites for the entire Puget Sound basin, the Puget Lowland, and lowland urban areas were used to display the coverage and resolution of the gaging network. For each distribution, sites were ranked from the smallest to largest area and the cumulative area gaged was tabulated.

Sites on large rivers account disproportionately for the spatial coverage of the gaging network-20 gages on the largest rivers account for about one-half $\left(13,044 \mathrm{~km}^{2}\right)$ of the active gaged area in the Puget Sound basin (fig. 3). Gages on river and streams with drainage areas less than $250 \mathrm{~km}^{2}$ constitute much of the network (232 gages), but account for streamflow from only 24 percent of the basin $\left(8,456 \mathrm{~km}^{2}\right)$, 25 percent (3,451 km²) of the Puget Lowland (fig. 4), and 26 percent $\left(961 \mathrm{~km}^{2}\right)$ of lowland urban areas (fig. 5). There are 119 active gages in the Puget Lowland with drainage areas less than $25 \mathrm{~km}^{2}$, but these only account for streamflow from $876 \mathrm{~km}^{2}$ (6 percent of the Puget Lowland area) or about the area of one large stream basin (fig. 5). About 60 percent the gages in the Puget Sound basin, lowland areas, and urban areas have 10 or more years of record (table 2).

Table 2. Number of streamflow gages in the Puget Sound basin, Washington, water year 2011.

\begin{tabular}{lccc}
\hline \multicolumn{1}{c}{ Streamflow gages } & $\begin{array}{c}\text { Puget } \\
\text { Sound } \\
\text { basin }\end{array}$ & $\begin{array}{c}\text { Puget } \\
\text { Lowlands }\end{array}$ & $\begin{array}{c}\text { Urban } \\
\text { growth } \\
\text { areas }\end{array}$ \\
\hline All sites with active and inactive gages & 776 & 593 & 406 \\
Active gages & 285 & 232 & 157 \\
Active gages with 10-year records & 182 & 135 & 93 \\
Gages with 10-year records & 306 & 212 & 149 \\
\hline
\end{tabular}

Table 3. Area draining to a streamflow gage in the Puget Sound basin, Washington, water year 2011.

\begin{tabular}{lccc}
\hline \multirow{2}{*}{\multicolumn{1}{c}{ Area }} & \multicolumn{3}{c}{$\begin{array}{c}\text { Drainage area } \\
\text { (square kilometers) }\end{array}$} \\
\cline { 2 - 4 } & $\begin{array}{c}\text { Puget } \\
\text { Sound } \\
\text { basin }\end{array}$ & $\begin{array}{c}\text { Puget } \\
\text { Lowlands }\end{array}$ & $\begin{array}{c}\text { Urban } \\
\text { growth } \\
\text { areas }\end{array}$ \\
\hline Total area & 36,666 & 14,131 & 3,681 \\
Area with active or inactive gages & 29,472 & 8,258 & 2,078 \\
Area with active gages & 26,993 & 6,451 & 1,510 \\
\hline
\end{tabular}




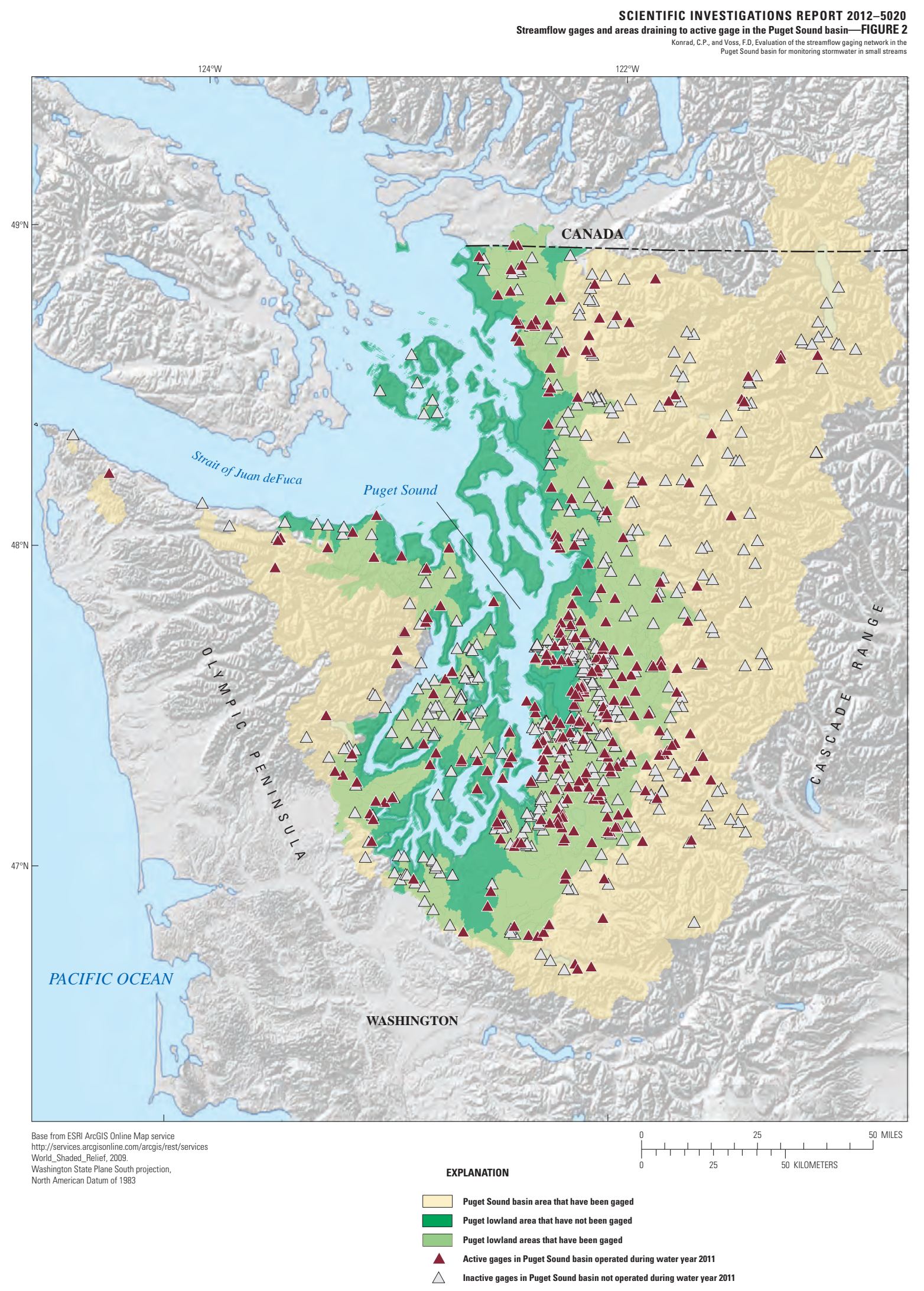

Figure 2. Streamflow gages and areas draining to active gages in the Puget Sound basin, Washington, water year 2011. Gaged lowland areas are light green and ungaged lowland areas are dark green. Higher elevation gaged areas are light yellow. Oversize layered version (11x17) of this figure is available at http://pubs.usgs.gov/ sir/2012/5020/. 


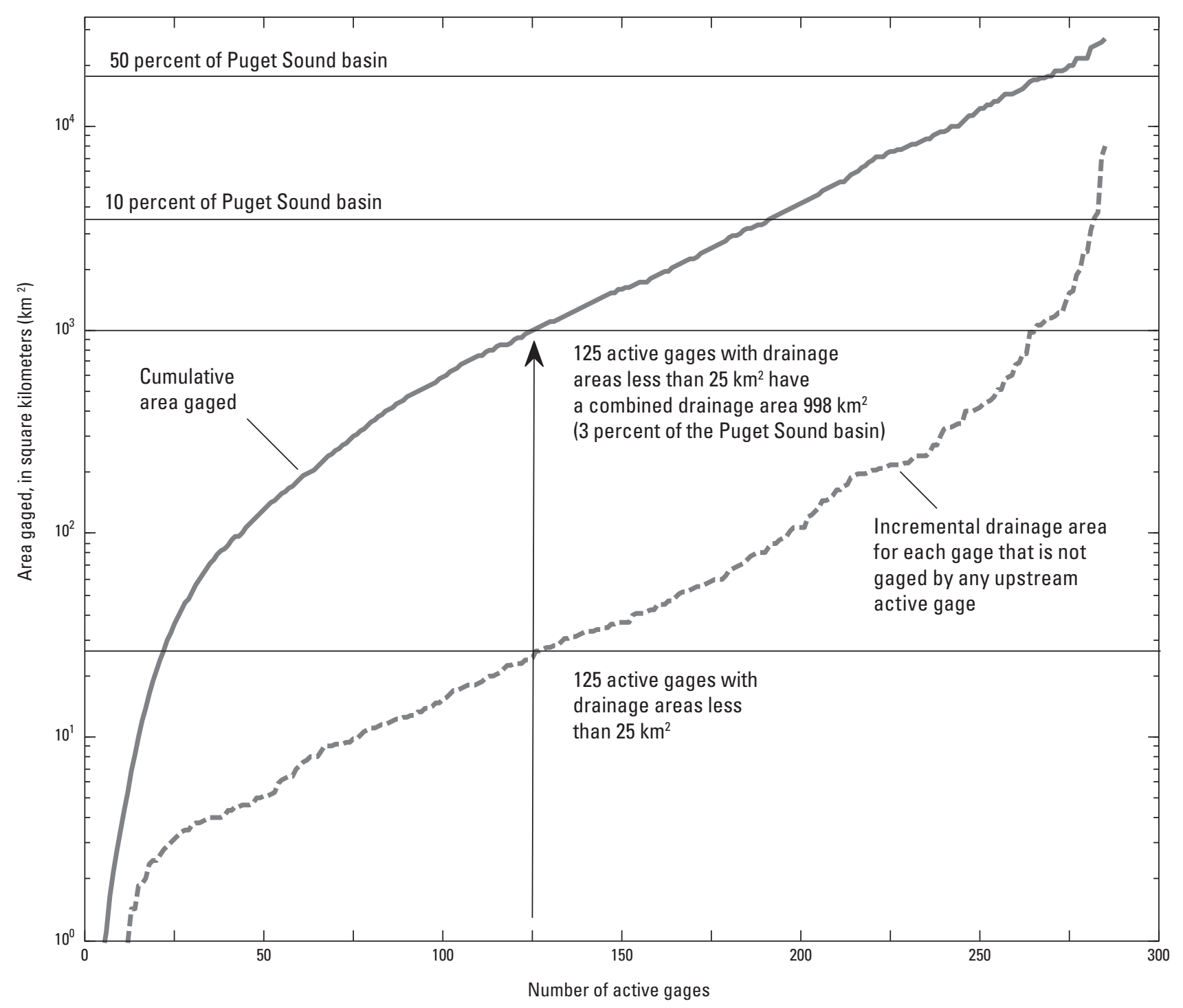

Figure 3. Distribution of active streamflow gages in the Puget Sound basin, Washington, water year 2011. 


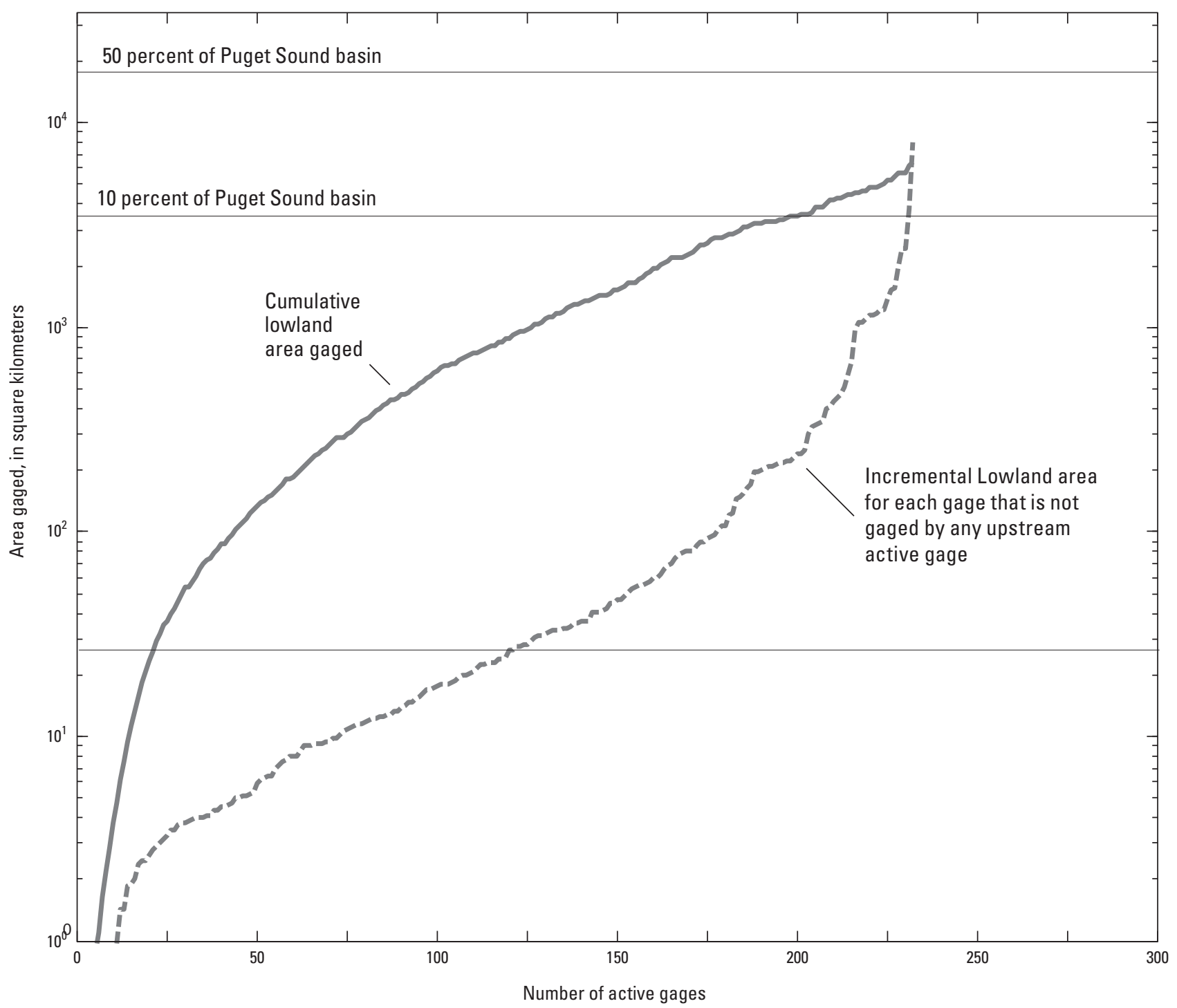

Figure 4. Distribution of active streamflow gages in the Puget Lowland, Washington, water year 2011. 


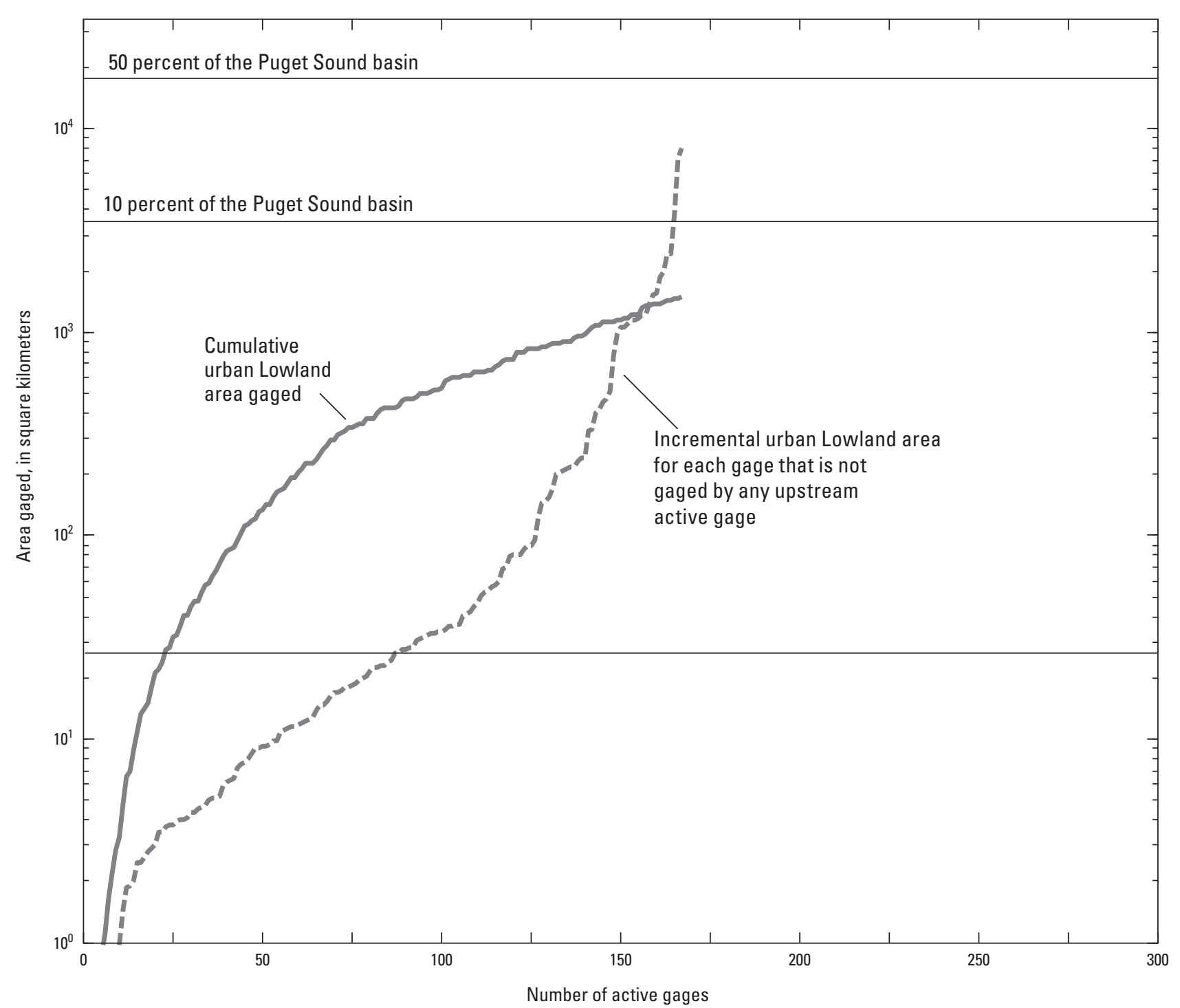

Figure 5. Distribution of active streamflow gages in urban areas of the Puget Lowland, Washington, water year 2011. 


\section{Gaps in Coverage of the Streamflow-Gaging Network for Monitoring Small Streams}

Lowland areas not currently gaged are concentrated around the Puget Sound shoreline (fig. 6) and generally are in one of four categories.

- Coastal drainage basins with small creeks and sloughs draining directly to Puget Sound (for example, Terrell Creek in Whatcom County, Samish River in Skagit County, Sequalitchew Creek in Pierce County);

- Islands and peninsulas with few streams (for example, Bainbridge Island, Whidbey Island, Key Peninsula, southwest Kitsap Peninsula, northern coast of Olympic peninsula);

- Large river floodplains and deltas with few streams (for example, Nisqually, Nooksack, Skagit, and Snohomish Rivers) or small streams draining directly to large rivers (for example, Eaton and Yelm Creeks in Thurston County); and

- Urban areas with extensive engineered drainage systems (for example, large portions of Bellevue, Bremerton, Everett, Seattle, and Tacoma).

\section{Spatial Structure in Correlation of Monthly Streamflow}

Kendall's tau rank correlation coefficient of daily streamflow was calculated at each of 21,868 pairs of lowland gages with at least 1 year of overlapping streamflow record. The median correlation coefficient for non-nested (not sharing any drainage area) pairs of active and inactive gages with lowland area was $\tau=0.56$ (fig. 7A). Only 9 percent of non-nested gage pairs had $\tau>0.8$.

Streamflow was more highly correlated for pairs of nested streamflow gages, which share drainage area, than pairs of non-nested gages. The median value for all pairs of nested gages was $\tau=0.79$ and generally increased with the fraction of drainage area shared by the gages (fig. 7B).The most significant departures in the correlation of streamflow as a function of shared drainage area were pairs of sites with intervening reservoirs, which regulated streamflow at the downstream gage but not the upstream gage.
Rank correlation coefficients indicate the best possible fit that could be obtained using index-station approaches for estimating streamflow, where streamflow values at the index station are transformed using a regression equation to estimate streamflow at the ungaged site. The maximum value of the rank correlation coefficient was calculated for each site from all of its pairs (fig. 8). The median value, $\tau=0.88$, indicates the potential to estimate streamflow accurately at most sites using an index station approach. Streamflow records at gages with high maximum correlation coefficients could be extended synthetically by making periodic streamflow measurements and developing a regression equation for streamflow at the discontinued gage based on streamflow at an associated "index" station. Although this analysis does not address how to select the best index station for a specific ungaged site, those gages where streamflow is highly correlated to many other gages would serve as the best index stations to maintain in the network.

Gages with low maximum correlation coefficients are important to maintain as part of the stream-gaging network because streamflow records cannot be extended accurately using regression-based techniques. For Puget Lowland, 48 gages had a maximum value of $\tau<0.8$ (fig. 8). These gages may be located in parts of the Puget Lowland or in types of basins that are under-represented by the current (2011) streamflow-gaging network. Such gages also could be useful for estimating streamflow in either nearby streams or similar type streams, but their value for this application remains to be demonstrated.

The decision to continue operation of a gage or, alternatively, to extend its record synthetically requires site-specific evaluation of the need for accurate and timely streamflow information. Flood warning or instream-flow protection may compel continued data collection at many sites. Further examination of highly correlated gages, however, may reveal opportunities to scale back from continuous monitoring to periodic streamflow measurement at some sites. Although synthetic record extension can reduce the need for some gages, it nonetheless relies on the continued operation of an adequate network of index stations that represent the range of streamflow conditions in the basin. 


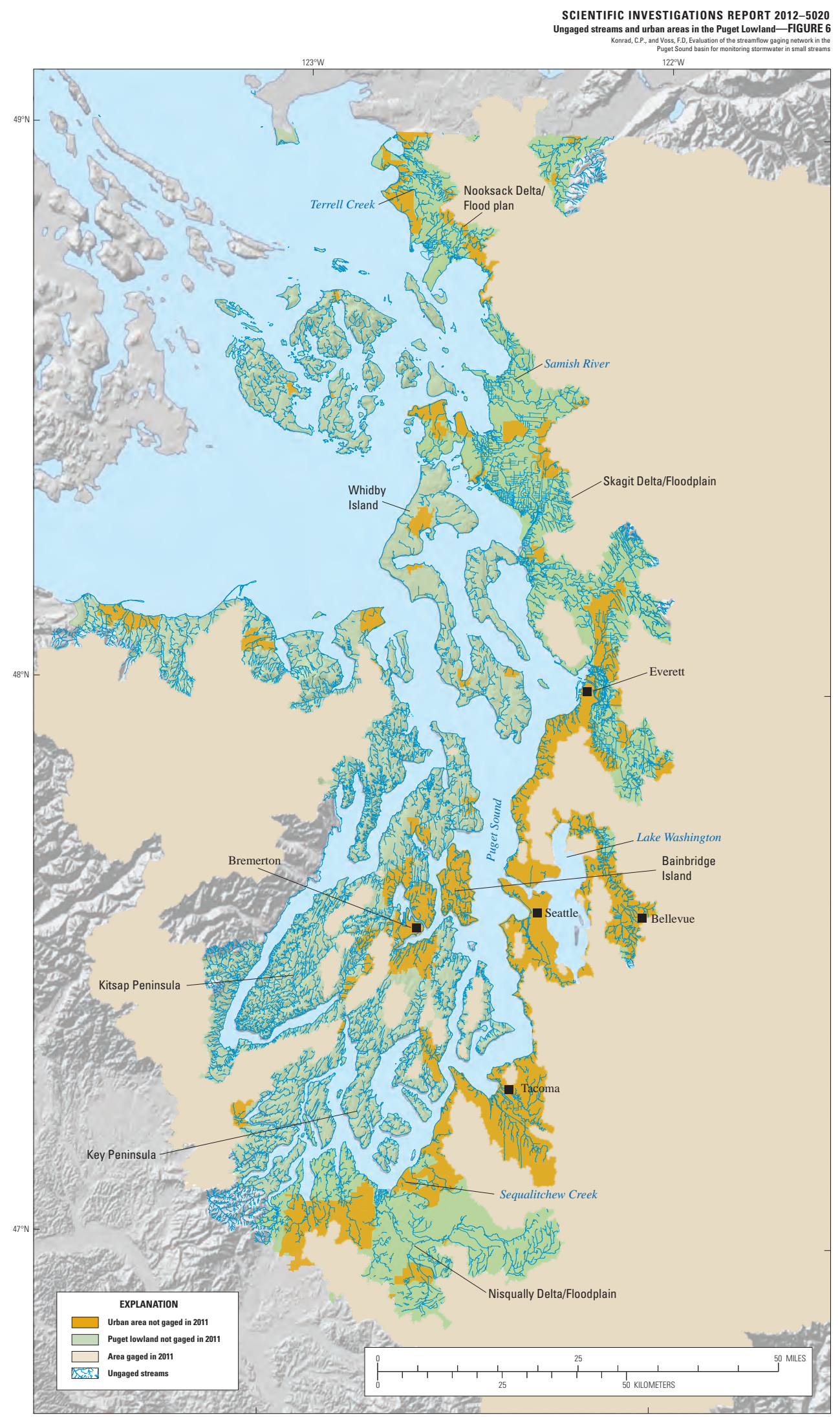

Base from ESRI ArcGlis Online Map service

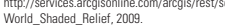

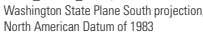

Figure 6. Ungaged streams (not actively gages) and urban areas in the Puget Lowland, Washington, water year 2011. Oversize layered version (11x17) of this figure is available at http://pubs.usgs.gov/sir/2012/5020/. 


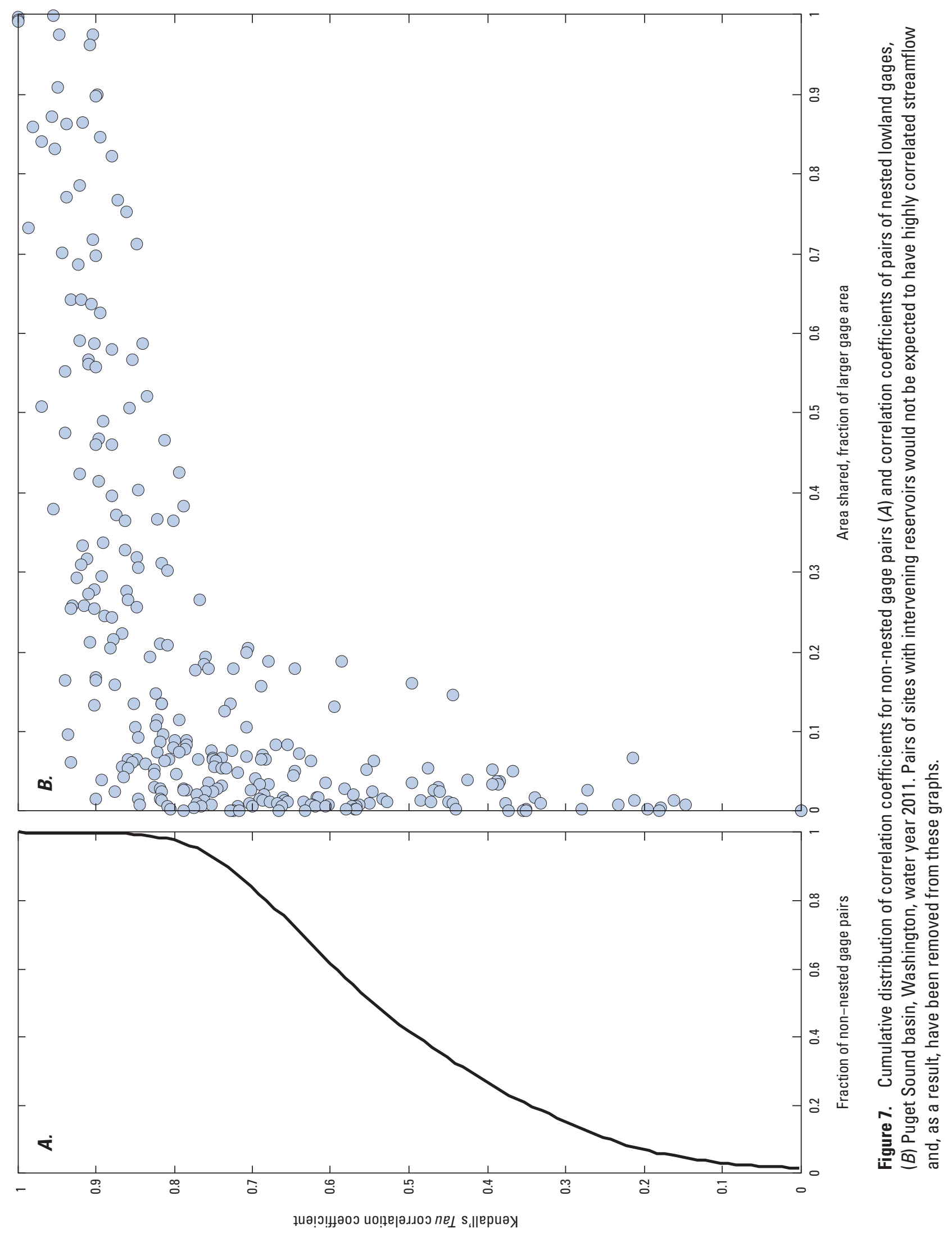




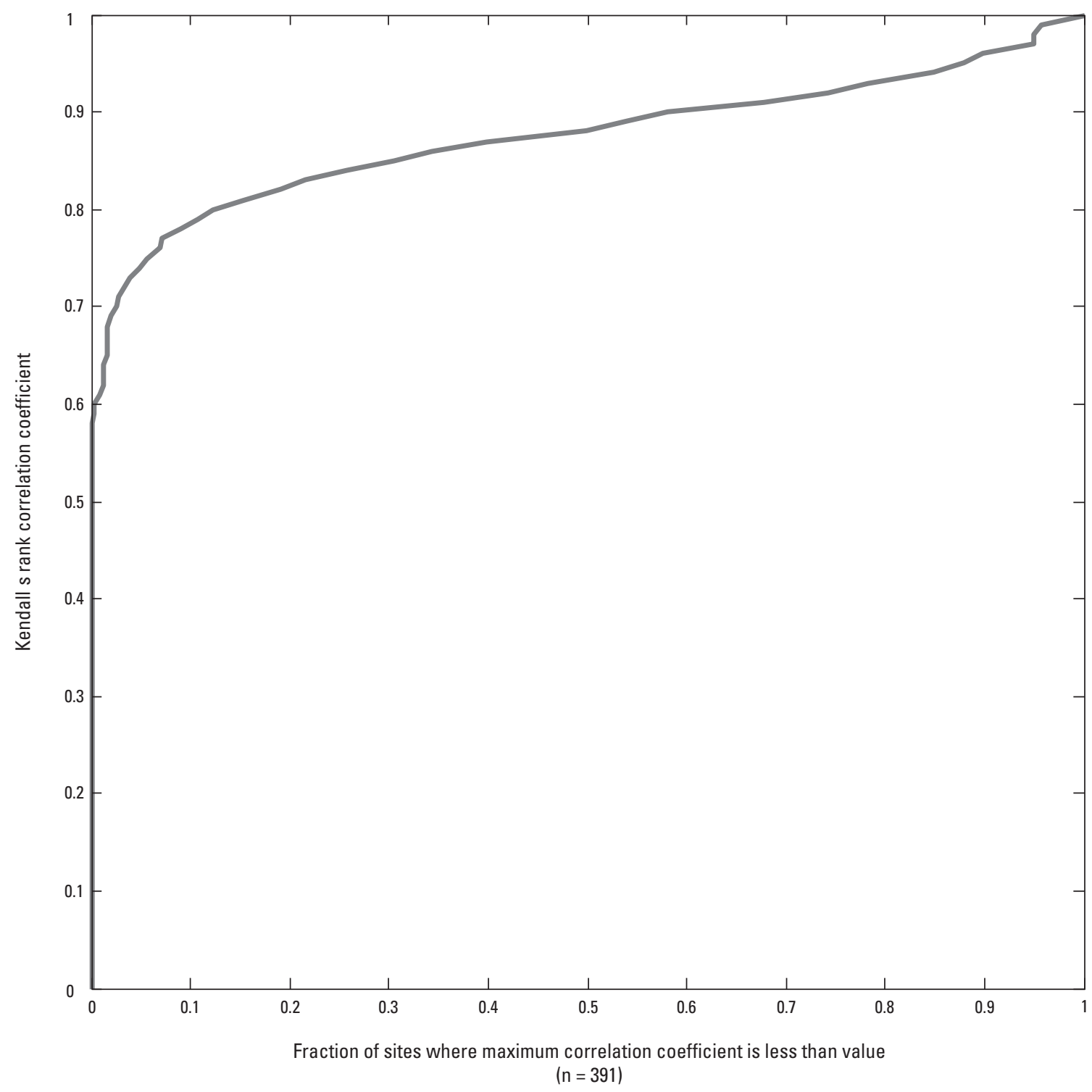

Figure 8. Cumulative distribution of maximum correlation coefficient for lowland gages not including nested pairs, Puget Sound basin, Washington, water year 2011. 


\section{Further Analysis of Streamflow Gaging Network Needed for Monitoring Stormwater in Small Streams}

Further analysis of the streamflow-gaging network can provide additional information for monitoring stormwater impacts, but the analysis should be framed by specific questions that information collected by the network would be used to answer. For example, evaluation of stormwater management actions could be considered along with monitoring status and trends in future evaluation of gaged and ungaged sites. The capability of the network to support streamflow models for ungaged sites represent a significant outstanding issue, however, any evaluation of the network for this application must be informed by how simulated streamflow would be used.

Three tasks are likely necessary for further evaluation of the gaging network.

1. Verify gage locations, hydrography, and drainage boundaries for gage sites in a GIS. Boundaries of the drainage areas of individual gages could be improved with high resolution topographic data, information on constructed drainage systems, and more accurate stream locations. These tasks should be coordinated with the Washington Shared Hydrography Framework Project (Washington State Department of Ecology, 2011c).

2. Assess basin attributes for current gage locations and ungaged areas. An assessment of basin attributes should focus on factors most likely to account for differences in streamflow between lowland streams, including geology, wetland and lakes, land cover, and local heterogeneity in precipitation ("microclimates) (for example, Kenney and others, 2011). The influence of basin attributes could be assessed, for example, by using regression analysis of existing gages to identify which basin attributes are the strongest predictors of streamflow characteristics of interest. The gaging network could then be evaluated for how well it represents regional variation in the most important basin attributes.
3. Investigate techniques for estimating streamflow at ungaged sites. The potential to use estimated (or simulated) streamflow at ungaged sites depends on the accuracy needed to resolve management issues (for example, are there trends in a given streamflow indicator?). Among methods for estimating streamflow, regression of periodic streamflow measurements at ungaged sites and streamflow measurements at "index" stations (for example, Pickett, 2010) could be expanded to the entire Puget Lowland. Further investigation of techniques for streamflow estimation, however, should be informed by criteria for estimated streamflow that define whether these estimates would be useful to stormwater managers.

\section{Summary}

The active streamflow-gaging network covers much of the Puget Sound basin including lowland and urban areas. Gages in the Puget Sound basin were installed to collect river-specific information rather than to infer the broader status of surface water in the basin. As such, many gages monitor streamflow largely generated at high elevations. Historical gaging sites do not necessarily represent preferred locations for assessing stormwater impacts despite the availability of long-term streamflow records at these sites.

Two types of sites are best suited for gaging stormwater applications - sites where streamflow primarily is generated from low-elevation areas (both urban and rural) and sites where land use and land-use changes in the drainage area are more homogeneous and, thus, more easily linked to trends in streamflow over time and differences in streamflow between drainage basins. Lowland streams with small drainage areas are the preferred locations for resolving stormwater impacts in the Puget Sound basin even as these types of sites will not substantially expand the coverage of the network because of their small drainage area without many additional gages. 
The gaging network can be used to provide information for estimating or modeling streamflow from ungaged areas. Lowland sites with relatively small drainage areas (for example, less than $10 \mathrm{~km}^{2}$ ) located in either in ungaged areas or in locations where gaged as part of a much larger stream or river will likely contribute the most useful information for regional streamflow modeling. Given the correlation of streamflow between pairs of gages that share drainage area, it is likely that monthly streamflow at a site with a discontinued gage or periodic streamflow measurements could be reliably estimated from a gage with at least 25 percent shared drainage area. Additional gages in a basin are likely to provide the greatest value when at sites with less than 25 percent of shared drainage area of other gages.

The active streamflow-gaging network provides substantial coverage of the Puget Lowland for assessing current status and future trends, given the large proportion of gages with at least 10 years of records. Large geographic gaps in the current (2011) network would require many additional gages because these areas are drained by small streams. Small streams wholly within the Puget Lowland and close to Puget Sound represent the most significant geographic gap in the gaging network. Such sites that share less than 10 percent drainage area with an existing gage would likely provide the most value in terms of filling information gaps of the current (2011) gaging network even as gages at these sites will not significantly increase the area covered by the gaging network.

\section{References Cited}

Falcone, 2011, GAGES-II-Geospatial attributes of gages for evaluating streamflow: accessed May 12, 2012, at http:// water.usgs.gov/GIS/metadata/usgswrd/XML/gagesII Sept2011.xml.

Kenney, T.A., Buto, S.G., and Susong, D.D., 2011, Analysis of watersheds monitored by the U.S. Geological Survey streamflow-gaging station network in the upper Colorado River basin: U.S. Geological Survey Scientific Investigations Report 2011-5081, 47 p. (Also available at http://pubs.er.usgs.gov/publication/sir20115081.)
Konrad, C.P., and Booth, D.B., 2002, Hydrologic trends associated with urban development for selected streams in the Puget Sound basin, western Washington: U.S. Geological Survey Water-Resources Investigations Report 02-4040, 40 p. (Also available at http://pubs.usgs. gov/wri/wri024040/.)

Pickett, P.J., 2010, Nooksack Watershed Planning Area: Prediction of gaged streamflows by modeling: Washington State Department of Ecology, Environmental Assessment Program, Publication 10-03-023, accessed May 12, 2012, at http://www.ecy.wa.gov/biblio/1003023.html.

Stormwater Work Group for Puget Sound, 2010, Recommendation for municipal stormwater permit monitoring, Report to Washington State Department of Ecology, October 29, 2010 (Also available at http://www. ecy.wa.gov/programs/wq/psmonitoring/swgreports.html).

U.S. Environmental Protection Agency, 2011, Level III and IV Ecoregions of the Continental United States: accessed May 12, 2012, at http://www.epa.gov/wed/pages/ ecoregions/level_iii_iv.htm.

U.S. Geological Survey, 2011, National hydrography dataset: accessed May 12, 2012, at http://nhd.usgs.gov/.

Washington State Department of Ecology, 2011a, Urban growth areas: accessed May 12, 2012, at http://www.ecy. wa.gov/services/gis/data/polsub/cityuga.htm.

Washington State Department of Ecology, 2011b, Puget Sound watershed characterization project data and maps: accessed May 12, 2012, at http://www.ecy.wa.gov/services/gis/data/ pugetsound/characterization.htm.

Washington State Department of Ecology, 2011c, Washington shared hydrography framework project: accessed May 12, 2012, at http://www.ecy.wa.gov/services/gis/projects/ sharedhydro/wahyfw24k.htm. 
Publishing support provided by the U.S. Geological Survey

Publishing Network, Tacoma Publishing Service Center

For more information concerning the research in this report, contact the

Director, Washington Water Science Center

U.S. Geological Survey

934 Broadway, Suite 300

Tacoma, Washington 98402

http://wa.water.usgs.gov 


\section{हू}

즘

ฏ

흠

宇

?

$\frac{5}{2}$

으

:

옹

4 Printed on recycled paper

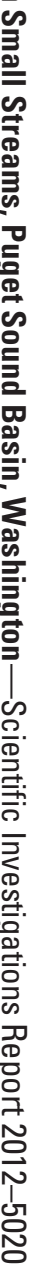

